なを方すパの断にてのいのな

分通がる। 理言つ共概いなく小 析しみこソ論でい有念かんと集

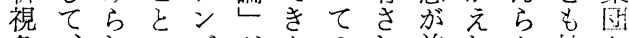
角、れのズがなのれ前れ加社加 の社る可なあい充、提ばの会ら ひ会の能どるで分主方作学食 と構たな劣を市張さま業的体 う造が立代も万解されざ仮諗社 は L

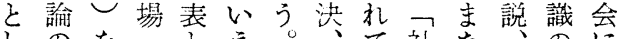
能

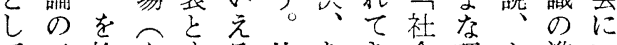
て二恰も方比あき会理な準い 機・.好つる。喻るて構論い拠た 能·可とこ的WW造的し杵る

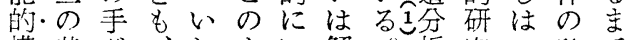
構·基が、わよい解怘析究一ひ至

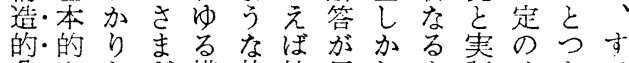
分なとさ構状社用し它証 1 之 析前しま造況会意なの的メして を提なな的に学さが唯研、ての

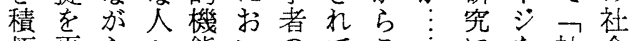
楩再ら々能いのてこ方にを社会 的检、の的て数いの公お前会学 に討々心理、注る基分い提棈的

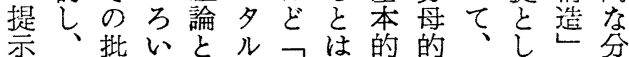
寸社判乃しコ社必な立社てに析 る会的なてッ会ず場会いつは

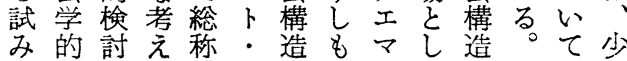

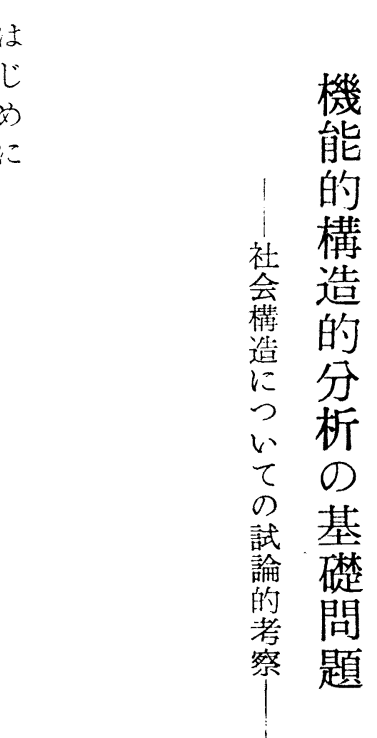

する視とるな各要りぎらの位析的は でするそきて面の役い用解役略に必 にこるれ問とをで割の語に割称理ず 前のいに題ら確はなでにこなし解し

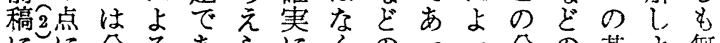

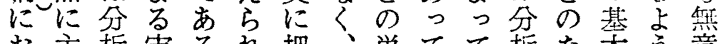
お主析䒠るれ把、単てて析な本引意 い要論璧こる握こな、示の吕的こ味 てな理的と社专れるそさ第にな考で 関々なは会るら言れ的求多るは $\mathrm{F}$ 心い理い的たの葉れるのめ的な

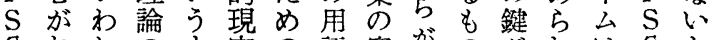

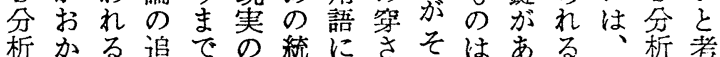

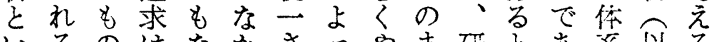

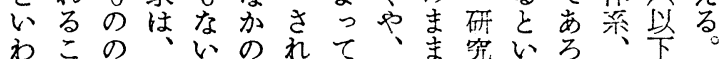
れと检そ。法た指そ分対えう機、社 るに討のこ則榴標の析象る。能機会 もなをまの的念さ形用の次能現 のろ前えよ関图交式具々心加的象

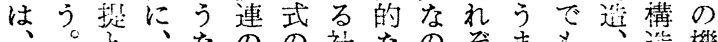

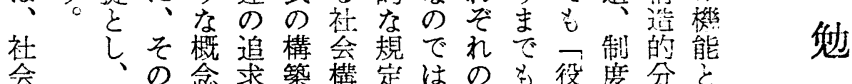

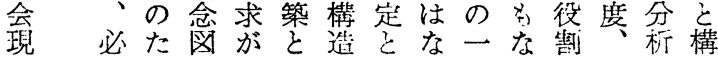
象要め式接、的論い部くの想を造

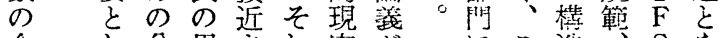

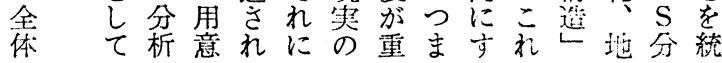


的重と一序けい検識本いうもしつ握為為性う関

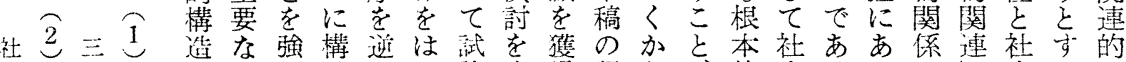

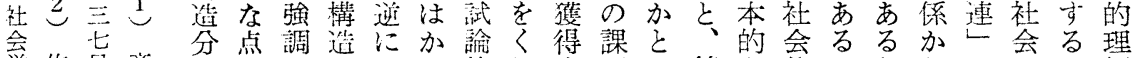

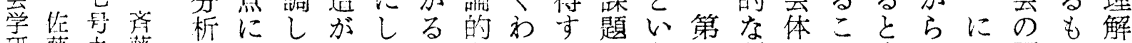

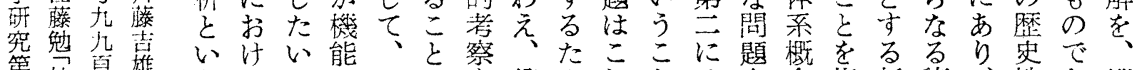
第社貝雄うるかにこに役め就点念指新諸、性あ機 公佘社二若ら、をあ試割のらでか汢の摘明集しをる能 号全匹会でしきるみの方のあか子検し教団た内と分

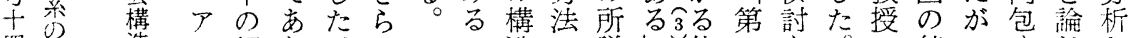
四基造ン相りがにここ造の説し体一を。の統っすずと

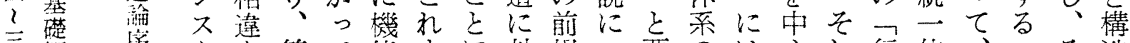

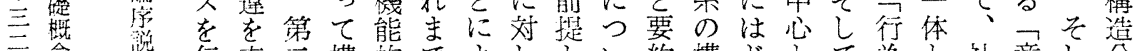
伝表示構的でよしとい約構どて為と社意し分 え明に非構のってしてし浩のしま関し会味て析 たしは分生構て接ての、と様なた連て学をそと いたパ析的造、近の若そ機なが前のの的と礼の

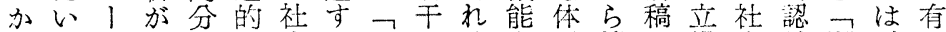
らかり機析機会る体のぞを系接に場会識関、機 でらン能と能構た系補れぞ概近おしのの係社的 あでズ分呼的造めモ充序の念しいの構基会接 るあな析称分論のデと説よを、て具造本のの合 りとに古析の基ル的う構 $\mathrm{F}$ は体と的綜本に の従ると体本し亦接に成 $\mathrm{S}$ 化機棵合質よ 第使属の心采的に亦近し守理この能題とがっ 至用しはう化なつるをてべ論の方のはし個て に法て、表の杵い体試ときの問问綜意て人獲 はかいま現基組て䒺みらかも題の合味のの得 锄らる导の整に更的たえとっにひ的的主し 態のこ第順つつに認。ていと対と把行行㡷よ

るを社るく社ななるめ概とにの規によ号事じ

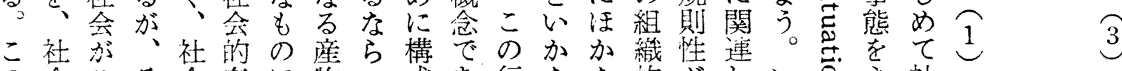

の会こそ会存に物成あ行なな的がしい方社

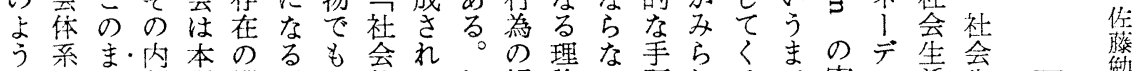

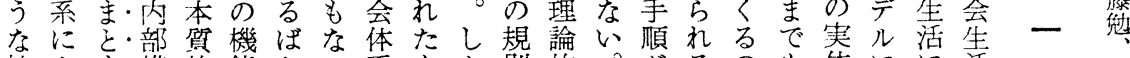

社よま・構的能かい系もた則的。がるのも体にに活

会っり・成に的り。はっが性定重存とでなをな参に

のてをは動至で

根も中相態上な 源口核互的命く社学二そっにのるこ加あ加てる定

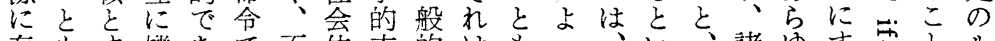

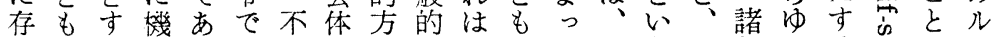
在基る能りあ可系法な社二てこうい個るる辛方い 李礎と的、る能はの概会般とのこい人社こ㣽でル

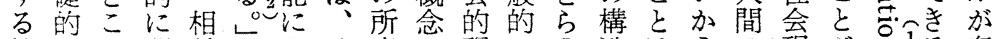

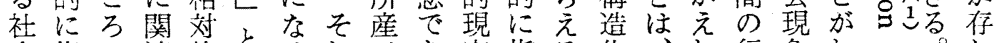
会指加連的とるれであ実指る化、れ行象わと。し

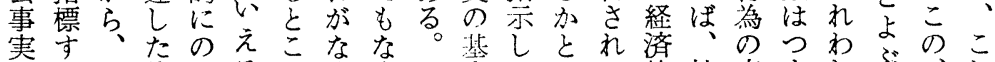

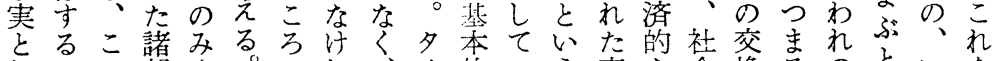
しこの部安。の礼、イ的いう事な会換るのといを て之根分定こ、梠抽ラ性るこ態社生にと課すわ手 のに源かしを個、象、格のとを会活はこ題ればが 社し的らてわ人生的のをがでぞ諸過なろでば構か 会たな成いる的活諸表指社あん科程に個あ、造り 体い社りるまな吕概現標会るな学にほ人るこ化と 系と会立のでら不念を高体。方のはどのとのさし 概考事ちでもび可の借る采法前一吕行い㞦て

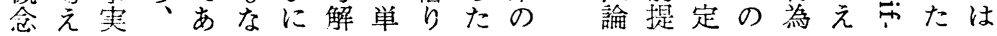


に機的とエやキ論考

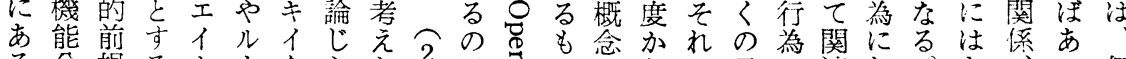

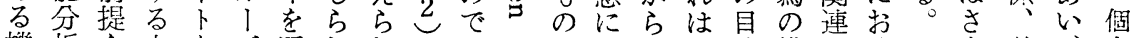

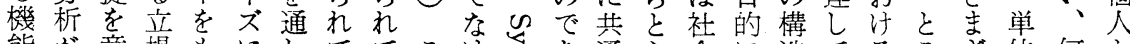

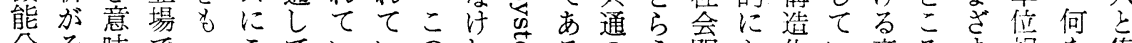
分そ味でっこていいのれ可领のえ関と化い斉ろま相を集

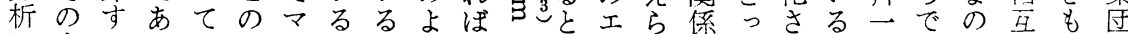

にまるっで言|つこうなでいレれれてれ事性社社間っの

対まもては葉卜狭とならなえメて集、た態会会のて屡 し社の、あをンい注社なけをとい団そ状とい体体相単開 て会でいる用な意ま会い犯う夕る態いい系采互位寸 ほ学あわがいど味方体。ば。ル。組最をうかの概関とる

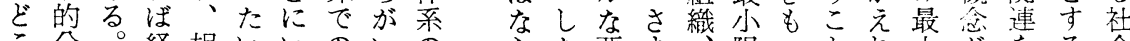
こ分同経相いいのいの方た要まま限っとれ小がをる会 さ析し駼互。た機な概なが素さ制のとでばのいだか的 れとか諸にそる能い念 るなし科依れ主。は 必るな学存はと義し広 要たがのし、いしかい がめら最あすうデし意 あにデ小っべ見ュわ味 るはイ限てて方儿がで で幾ヴのいのよケ国の あ多、論る要り要り機 ろのス理し因もかお能 う留のあこは、占い主

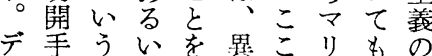
イ術よは出っでノ盛枠 ヴ方う基発たはウん内 1現に本点ウやスにで いっと立度単安三要乃のと行 して、の、位二る人件いる心為 社そレ構は般。次はろううの 部会のへ造役的こ正、のにこ相

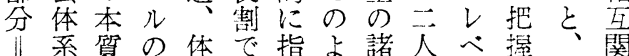
単は的一制あ古う個以儿市な連 位つ属構なる分に人上でるらを のね性造どと析社がの構かび中 自にを学の心用会子諸筑にに核 律経概にさえ具体役個さよ全主

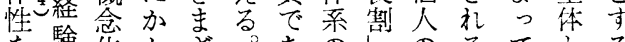

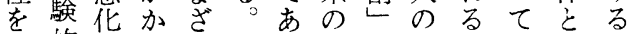
容的しわまつり概を相こ具単 認にてるなま念通至之体位こ

をるにきる歩の自自のえとるる部に造能在しみにつけ 正。焦で。み位身身場らは機貢分おに分してる対のるに 面そ点あいの嗔の最合れ明能献かい対析て部こし操こる

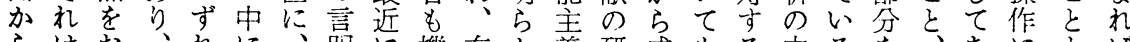

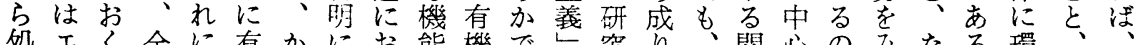
処エく全に有かにお能機でし究り、関心のみなる環 理メ、体せ機なもいの体あはでた機連的でるい部元一煲 しッ正によ体りかてを主る部あう能の才あをし分さつ能 う卜確対、モのか再らデ。分る全分研りるいは品れの分 るのなすこデ変わびえルつのと体析究工。う全一る部析 モ心意るのル化ら言方とま全さとこにン用、体定。分の テう味貢有かがず明はのり体れし正あテ意せ社のそを根 儿目で献機らみ、しキ完そにる9確る!深ま会機し他本 で標ので体解と全てヤ全れ刘。のにとシいいや能ての的

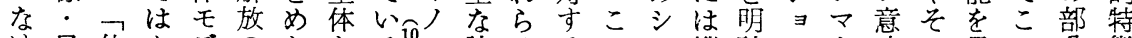
け目体なデのらとる馀訣はるの不機確ン1味の果の分街 れ的系くル過れ部。の別生貢よテ能にはトで二し操には ば・モしを程る邻しそを物献う允を表はンの部て作対 な権デて社を䟚尔年ににに通現あの機のいのし社 ら力ル、会よあ関しとくと主みおししるば能必る根て会 なとし全学みる連パ全もの要てけててパあ主要も底関の いいが体的子意の、全のアなくるのい夕い義やのに連諸

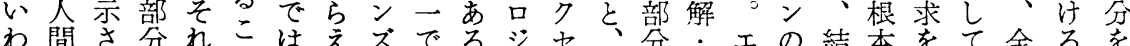

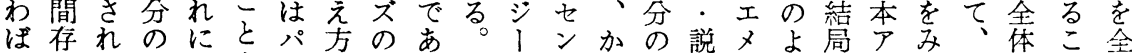
有在る構再も!やばるパに卜れ全朋”引のイたそ的々体 機のべ造構可り均あこ1おをら体り卜大とデすの社とに

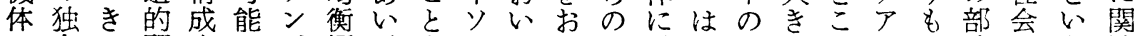
モ自で関卞でズ概、をンてくい対、指なろがの分体う墥 デ性あ軽べあの念彼彼ズ考こう专諸摘構機存と菜三主 
く的ばの方とた理っるるらが因一験の析関ろ的べル

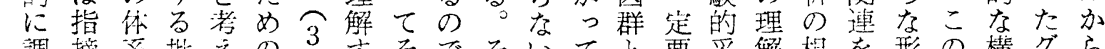
し調㩲采批えの

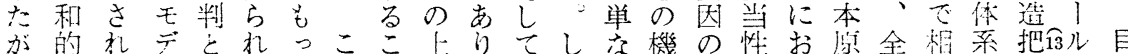

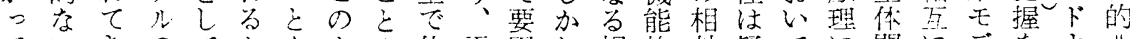

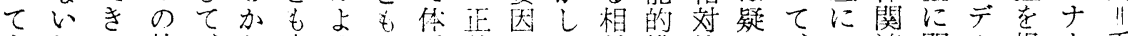
まして静、方底う可突確理た対構的わ、注関儿視1手

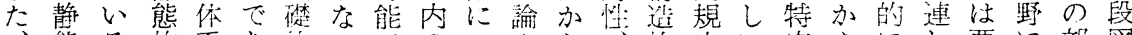
態る的亲あ的いるら的定い定なにし要に部图

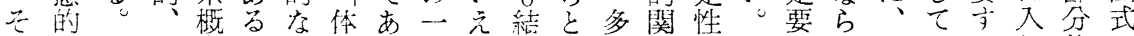

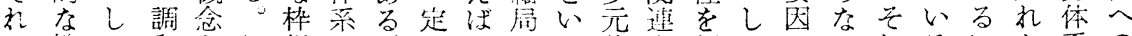
が临か利あう組モ。のこいっ論を仮かのいしるにた系の 变格し的る肪亡デ要ことての分㳬し絶でてと社モの成 動を体性い国しれ因こ无主析しな対あ機い会デ独長

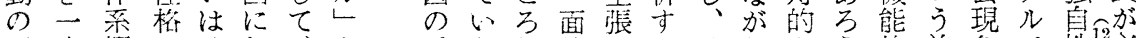

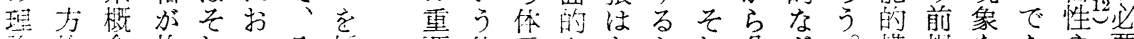

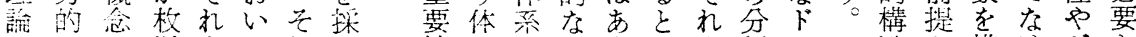

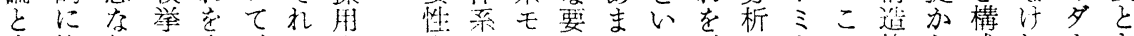

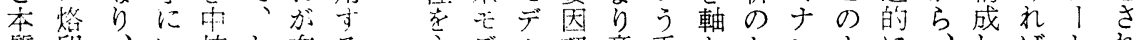
筫印、い核と有る辛デル理意手とたシはににしばレれ 的さ体と方效の張的を論味順しめ不理個てなるる

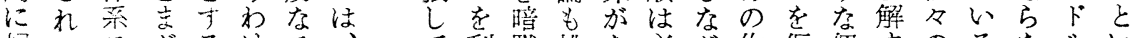
相てモがるけモ利默排な必が作仮個要のるなルい 反いデな認パデ社 い用のさい要ら業定々る要諸いフえ るルい識 るるなほ方ソを学のる提るいあそ説る要いと因いう

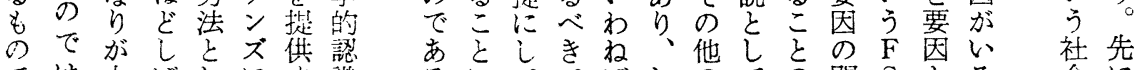
では本ばしに李識るにてでばしのての関 Sとろ会に もな来して対るの

なっ現とて的用れ㕕落いて点提で体に念理解に一広承な

らこ状らはにはるの念古はな的あ采処㜽論秎わ般義認い の維え、背経性現心゙すを゙る概理式をにた的のし

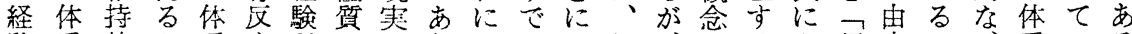
験系的加系卞科ののりせにつし、注よ経来パ系いる

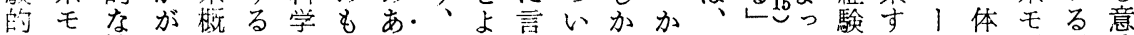
な $゙$ 性重念とののり・し、度ても出一分て的るソ采デダ味

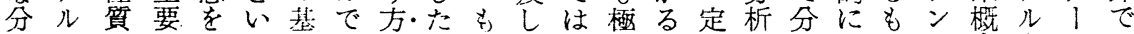
析はにでぞう本はにがこたか端体境枠析統のズ念をレは 方、よあう見前なつっをこなに齐界組さ合とのに暗ン苛 法飞っろ構解提いいてとをり強の内とれしい発対默ト酷 のれてう築になって特值がの調存に考ねてわ言すにルな

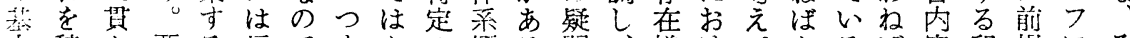

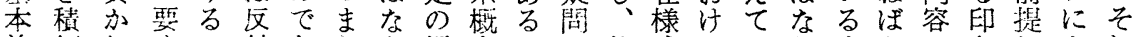
前極れす出刘ありん领念のが体式るいら全なに象しるし 热的てるとせっ体ら域はでい系文諸るな体らつのたるて ににいにいざて亲かに高ふだして変のいるない共うパ半 な提る体うる、概のお次かか法て数で問しいて平え1面 つ唱の系こをそ念具けの入れ則均のあ題て。の法でりで てすでモと㧈の体る推门るな衡相るをだ゚、展ンは いるはデとなが導性経象古で゙と互。もは1や一開ズパ るかなル共い值入を験的るあを境依もつなりや九さ批

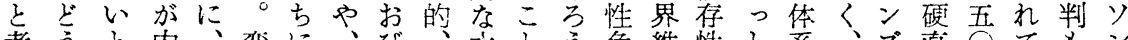

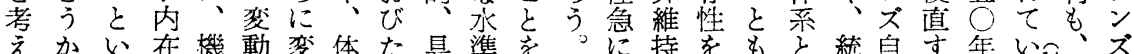

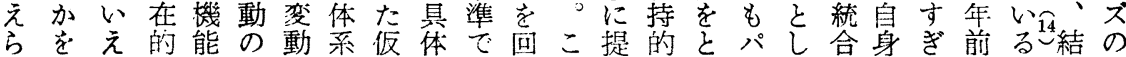

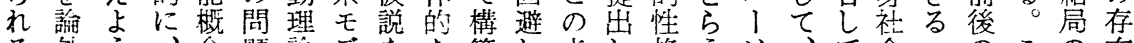

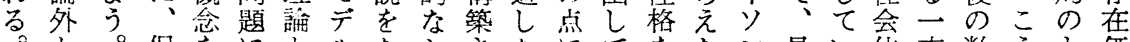
そ告。保をにとルたシさたにてをたン具い体方数うと価

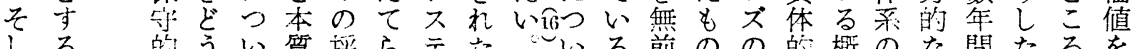


な祝、えミ現及意れなリる系いるれ係にきがて合わて

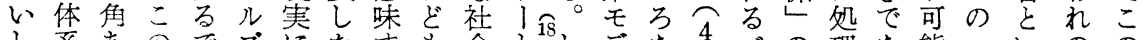

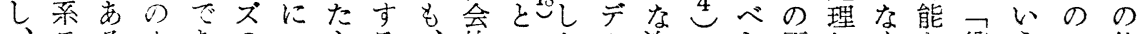

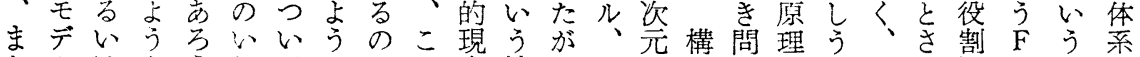
たルはなう方てにでの実性っいの造題的るこれ壳 $\mathrm{S}$ F

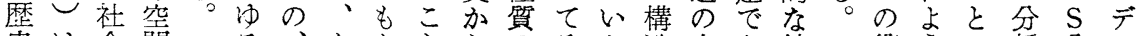

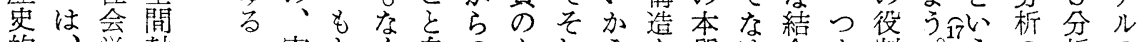

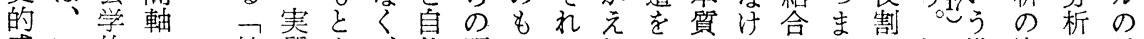

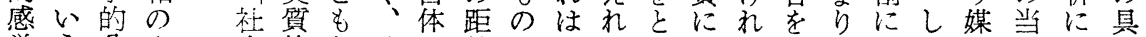

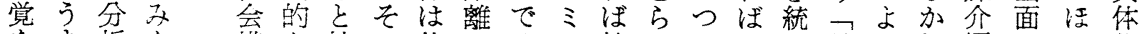
をま析を構な社の体のはル社えいな一役っし栕のか化

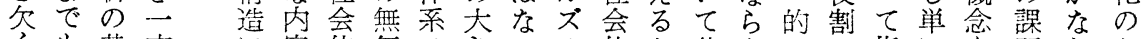
くも基方に容体価飞きいの体た基なにの指にを題らた もな本的つの系值デさ。い系め本い把構標役導はなぬ のく的にいそののルのこわのに的の握造さ割人次の で時な強てな一論とたのゆ一はなでししれ概す形。操 も間命調のわ般拠いめ社る般、理あうのる念る式機作 な的題し作っ理とうに会空理基解るる中最のこ能的 い要のて 業た論な一抽体理論本を。概に小可とと分な ”因整い伍理はる般象系空が的得念み限能にて析方 そを序る説論特の理的の論前なる。图らの性よ内法 れ無々。定で論た二的提分た式れ構のっ容構論

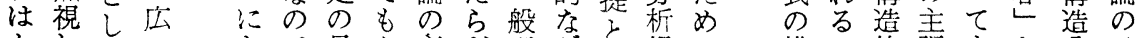
かしていちで具な必ざ理グと視に構的韭まと分ひ

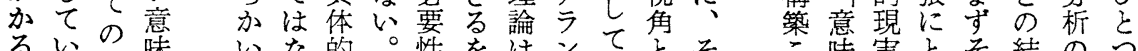
るいの味いな的。性をはンてとそ味実とそ結のう

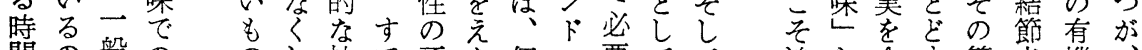
間の般ののし社で否な個! 要てて追と全ま第点機 軸で理分とて会に認い别セにのい求面る年的わ とも論析い、的言をけ的才な体ろ関的へ歩し統れ

仮と同求優分てしでるまる分づ先を限な意は築なすな相 説空時し先ないて構。さ。析けに備定章味事さいべの反

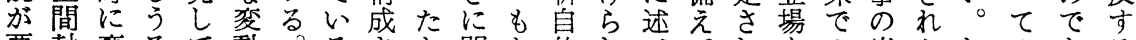
要軸変るて動。るさと問ち体れふてれをの半たしのある 求と動の問分しとれえ題万のてたいた要一面の加条るも さのので題析かいて注はんない理るあ約般しでし件る。 れ接一あをのしえいパー時かる间するす理かあ二代時で る点般り設用こるる、般間にのにの範る論見る般み間は のの理、定意の点けソ理軸変でよで囲もはてか理た的な

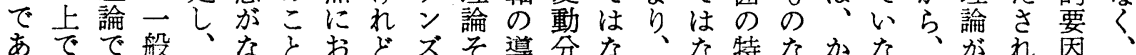
るの、理そさにいもものれ学析い恋い定の加変本るをそ 汀論これよてて二自㤎の。動しのだる結動来の導れ 構れはにてっ、結般体問要問分、社少社果の的で入と 造は䍩はいてか局理の題件題析ま会ら会と分にはうの とななじる、なの論構解をはにた現、的み析形なた正

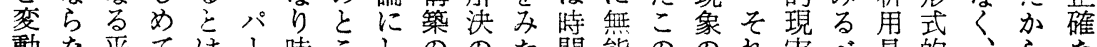
動な平ては!時こしののた間能ののれ実悬的、らな とい面空いり間ろてし実す軸力ょ分はにきと接

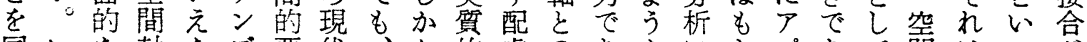
同いな軸なズ要代、た的虑のあなにとプあて間はっかが 時わ構々いの因西抽になを接る角つ名吕不的一て要 に浩しこ二を欧象汃展し合こ意いと！。適配つ、求 視理詥て時般導社度加開てのう息て時チこ当虑の歴さ 野想での間理入会のつをおしを航前史れ に的あ一軸論しの高て意おか必充的るであの提的る 入にる般がのた理次い味くた导こ分際いるみ条認性 れはよ理空な形解のるしことしとな空のっと基件識䓄 た時り梳間かにをしのなと多自る間一ていいに視の 作間はを軸になめへでいで構運体用的般いうてす角も 業朝、要に充っざルあ。あ造命は意に的るの構ぎのの 


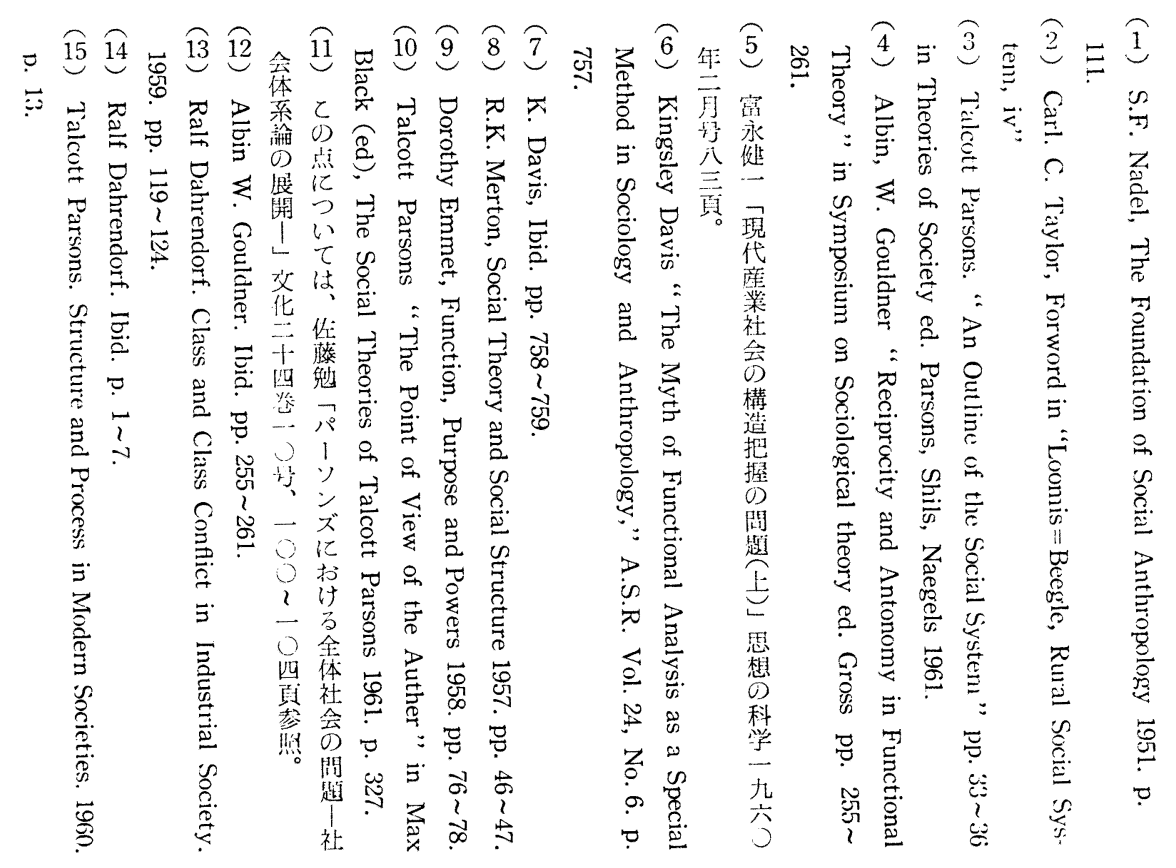

き析的なと等ま性団すし提しおあめ

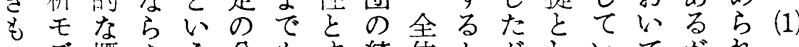
のデ概なっう分も方統体かがしいてがれ

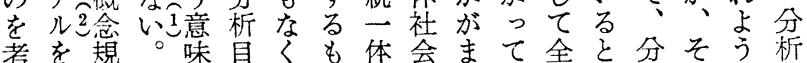

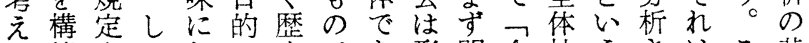

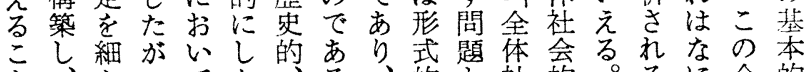

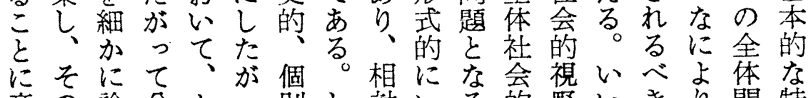
意の論分かっ別し村いる的野いきり関特 老枠导類なて的加的えでしに行も連徽

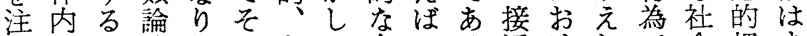
ぐによ的任のあこ自一方近けれ等把ま へおりな意範るの立定う方るば夕構握ず き讨も以的国い全性の。法構、! 造と全 たる、し芯は体、地と造全ン的い体 全い問操限程社包域 考体わ題作定度会括をわ握関景景連 え社は関的さ的の性基れを連らあは的 る会そ心なれな現、盤る要的えるい把 。接の别も本实完に求把占いわ握 そ近概的のあのの結しのし握うはばへ し方念なでるであ性てがてはと全究の

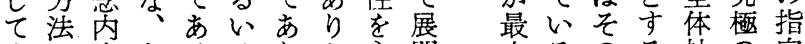
全々容あるはり亦開尔るのる社の向 体でると拡、たな限の基姿会目の 社もしいい大心は形犯何で本勢的標な

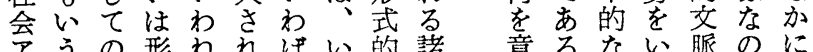

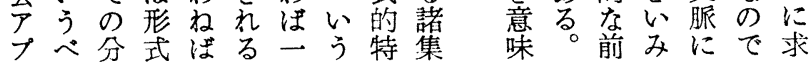

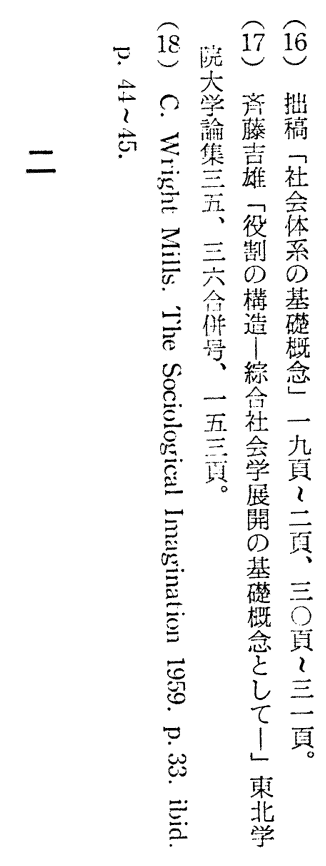


うでいと理さそのやいよと考 会こに棈に社志はそえ口

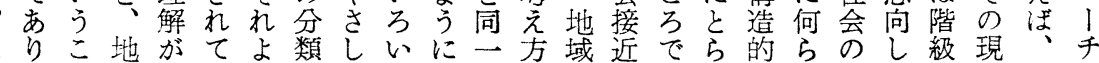

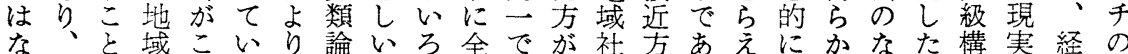
は前に社こるもにはのくあ展会法るる基のかも法の済た だ者な会乃こ地対ず地異る開に会とこ本まののな全めめ 形のるとみと域しで域なとさつのいと的と一でぞ体政の 式構。全らと社てあ社るかれれい本えをなま定なり社治充

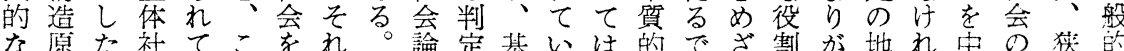
規理が会いの論ほ全の唯礎る周なあ琼な域ば心基義な 定がっのる地じぞ体中く社。知属ろの集け的な視底の パ をそて間こ域るの社にた会たの性うが団れ範ら点的社

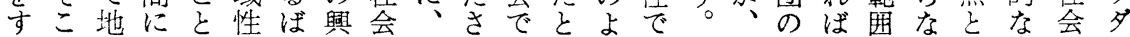
るに域はにをあ味にいれあえうなこ全機なをいし構なイ

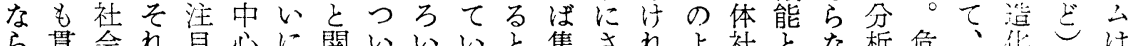
ら貫会れ目心に関いいいと集される社とな析危、化しは 、くは汪しとは心てろるか団ま法う会構い目険全彺を 地こ全ぞたし市述のし、類ざなな抮造が的な体理包社

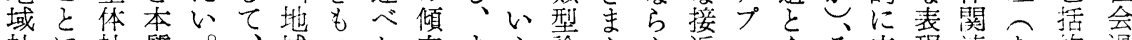
社に社質。、域つた向まや論なな近口をそ応現连た的過 会な会的こ社性必とをた派の角い方 I立のじが的とに程 はるのなの会要同自現生立度と法手体範て部分え視の 一と地差後生がはじいに社場吕考はの的囲限さ顺ば野主 定い域兾者活なな理出試会加らえ同第加内定れを資に要 のえ的はをのにい闲みでら、る3時一つにしる試㐺叹な

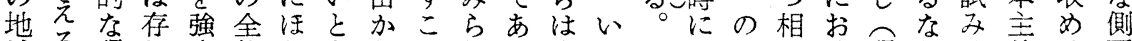

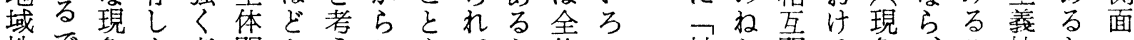

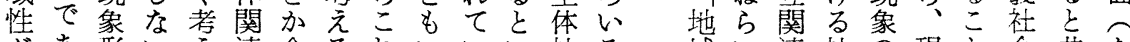

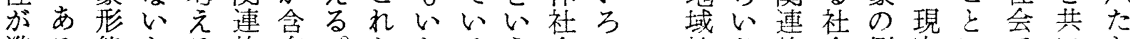
準ろ態とる的有。らとるう会の社ぞ的会側実にたにと

域充うわ果まと連基るていでと的の人本程のにが䈌れ拠 の足にねでりいと本諸地すあ㕫生間的の出つな再は枠 範守、ばあ地うい的変域るるる空活のな主発いいが極々 囲る地なり域上うに数性こ方生間夯社学要点て限準內な に範域ら、性吕下注のをの考活的集会イなとはり拠てっ 形两社なそのらか広追維地え行限中活テ規し生、㗎抽て 成、会いの原のらい求持域る為定吉動ア定た活実た象形 さつと。意理理の意がす性。のとる唯で条い機質り度成 れまいこ味は解理味必る原そ必集傾空も件と能的うのさ るりううでいの解で要条理れ要中向間あと考となる高れ 社日のしはわ綜とのと件ので性、が的るなえい意のいて

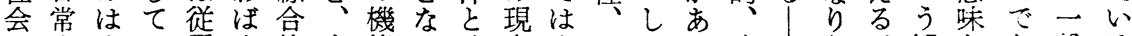
䅉生こ属生的全能るそ実生こたる時う方観ああ航る 不活活れ変活な体主。れ的活れ加と間をる、点いる的社 テののま数機検的義こをな過がっい的考理そをはかな会 么相たで的能討な的の解意程地てうにえ亩の導うと規シ で対め述なとに社発諸体味に域地こ限て|前入すい定ス あ的のふ意体よ会想菱すあお社域子定み|にすいうだ るな最て味采っ構の数るいけ会性でさたそそると点あ㕕 と全小きあ機て造なの条とる概をでれいれもこいにっで

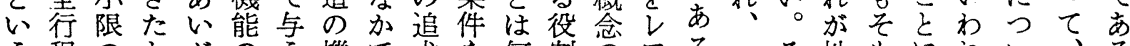
え程のと泫のえ機で求を何割のフる。そ地をに放いるる るを生こ強、方能、の方で配根ア。定れ域地よばてどと し可活ろいあれ要生ひンあ分底レつの注域っなのんい 能機かもるる件活と卜ろ・にンま地ひ会性てら明なえ しな能らの種と】機う口う役あスり域と概㔔な確理る たらを明での考構能の、加割る!生の口念社そいな间 がし相らあ接え非】糸ル。実アポ活範にの会の作でし つめ対加る合る化生にしこ現イイの囲いも生解こ業二方 てる的なとの。原活はてうにテン時にっう活決の仮定し 生地によい結つ理関いいしたアト間彼て基過策点説のこ 


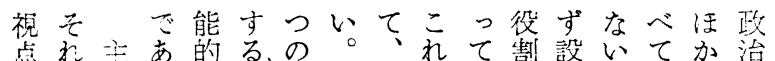

意に要豆要位役社経ま本等定。のに治と

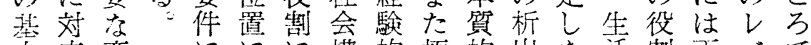

本応变ににに構的極的出な活割闭べで

条主数たあ結街法めにと汀に関者儿全

件る:

の役效

U 割 寸

之心

いる昆的則て重心れと係のを体

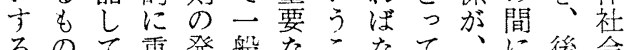

㭆のて重発媻なこな機々ら基す本者な

分包

は析括

と的

剨しるなに、能をな本心貿がい

あいな 対のう割そ遍役量。な同な域地

らう関 応役なと力的制しこ機じ差性域

$\Phi こ 心$

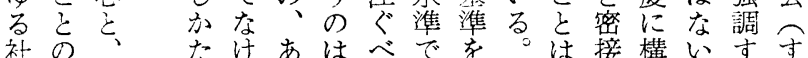
の割もいをなのての能程異を社

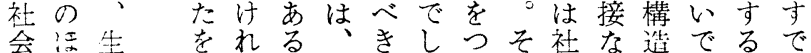

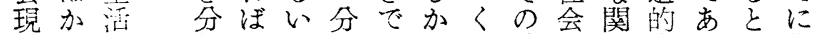

象にに析なは析あもら前構係意乃指

が、亡し他的るのね提造に羲うう摘

個社っななのなこがば条論あをしアし

人会て讨諸諸飞言な件的るものクた

の学基れ。々機はえらとに役っ内セよ

役に本ば体の能いななし重割て部ンう

割固的な系役体ういいて要:いにトに

実有なら機䓶亲まの。社な集るおおの、

現な機な能を古ででし会機団のけ差前

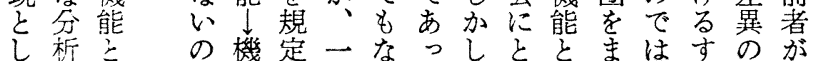

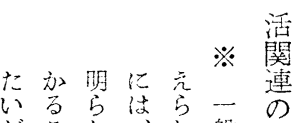

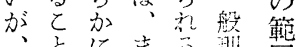

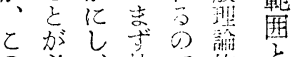

の必社它的と

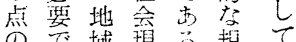

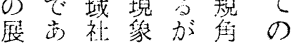

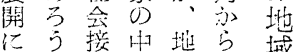

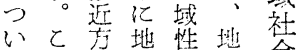

心と方地性地会

仗は可性コ社と

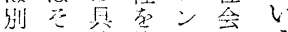

の华位占范

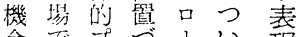

会でナづい現

利心名、出采

用のう地て以

しでム域い上卡

いれ設会諸よわ

之以定概変 5 洁

考上の念数なで

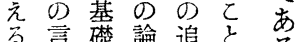

。言礎論追求方る

はけ構のま

せ起造な恋

社な嫧 (2) 汁で学をを定人提え個イ視究をれ独すのをて

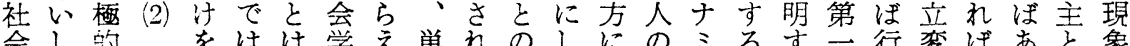

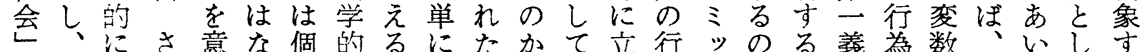
のこ展き味く人なの客行かいつ為》でを的パを行にてる 観の開にし、の分で体為わるものなははに社為お社こ 念言さのてか側析なと様りのの構かないいい（会パけ会と が葉れべかののく主式あでで造かくうっみシ構夕る構を 全をてたるる変ひ、体をいああ的わ.、てしの造！社造認

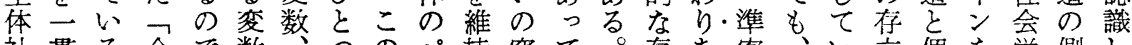
社貫る全で数つの公持究て。存あ・客、い立個を学側し 会じ㡷あの心の独ラし明、そ在い観そるを人分的に二 的て彼社ると理焦章坚吕加意の的れと条の析な求ら 二使注会。り学点変ズ変可かは義ななは心件対の視め沿

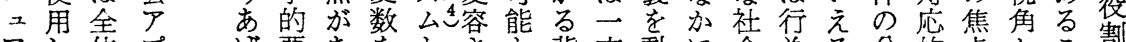
アし体ブけ要あをとさと背方動に会為る分的点かこ割

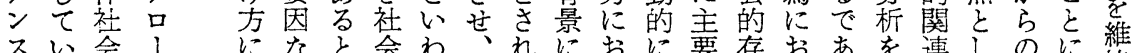

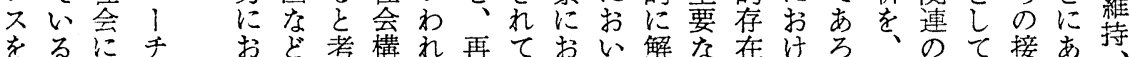

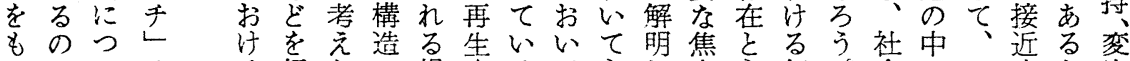

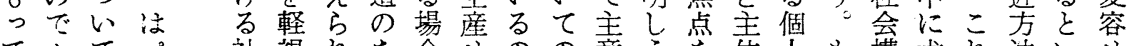
てもてパ社視れな合せのの意うを体人も構求れ法いせ おな朋 1 会古るかのしでみ主る見的のっ造めをのわし り、確り 学る。によめあ義鍵いな主々的る存特ねめ

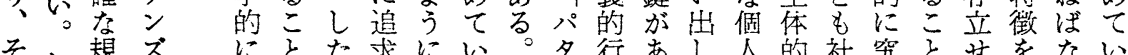

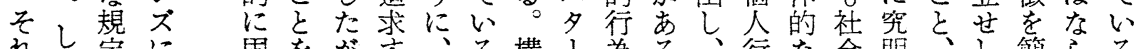
れ定に固をが索、る構、為る、行な会明、し簡らる

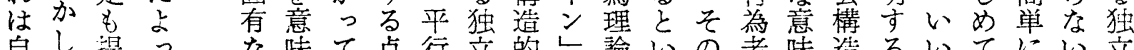
自し提っな味て点行立的し論いの者味造るいてに心立

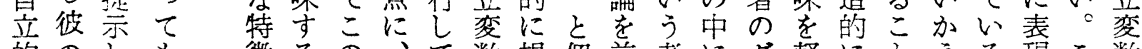
的のしも街るの数規個前考にタ軽にとえる現こ数 


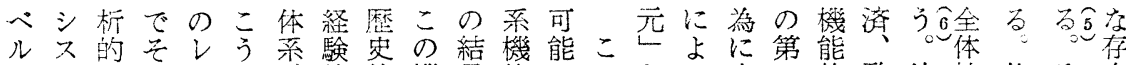

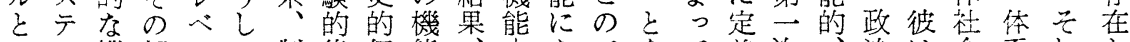
い厶機相ルて制集個能、なパをて着次、治は会柔㣔と うの能互、社度積别体一機る! 考規し的構、社气幾はし

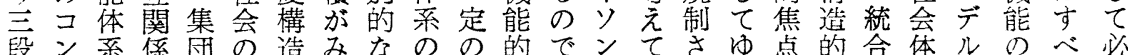
階卜とをの構方諸分体要はスいれくをな采を分て要 に口乞考レ造具れ案化采件な.るつつつな相パへき数のな

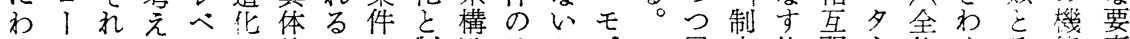
けルをる゙ル・的うの制造ラかテ展度体関、体めそ能委 てを中方にと集まち度がイとル開の系連ン的ての的を

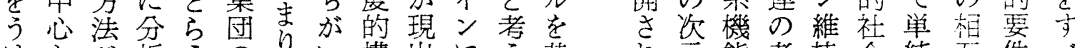
社 会なし有的る関ろに造す沿る本て必祭し体化関をて

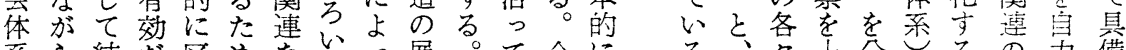

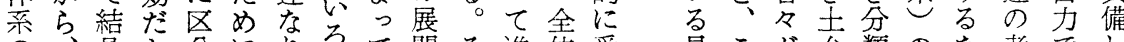
の、晶と分にり、て開そ進体受具こが台類のな考でし 構展し考しは、条、にしみ社付体れ制としなら察䙘た

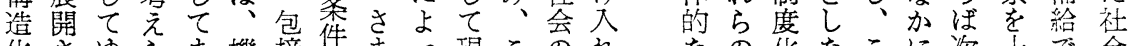
化さゆらま機接售ま口現このれなの他なこに次士で会 の市くれ方能関のさて実の構つ行体さがれ四の台き体

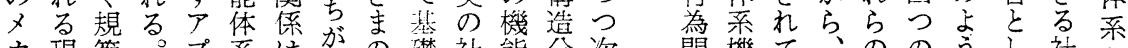
力現範。プ采は恕の碟社能分次関機て、ののうう社系 三実体く品の異に多ら会分化の 連能個構機機にた会考

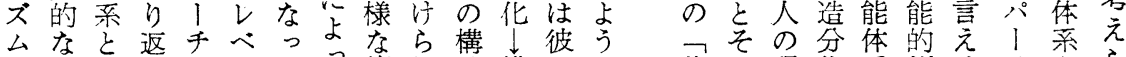

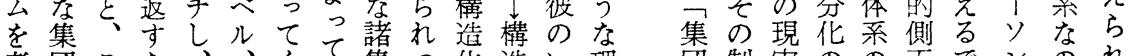
考団こな、、くて集つ化造い理団制実のの面でンのれ 察ののらつ制る機団つは分う解の度的方間っあででて でレ両分い度。能のも华体が次化行向の経乃の㐫い

と持脈なむでるいそいそ機次べ のがと棌、加れとれ能元て

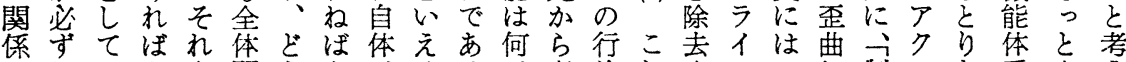

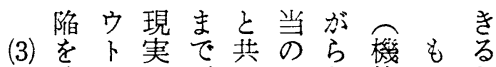

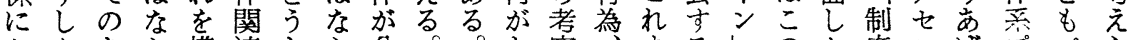

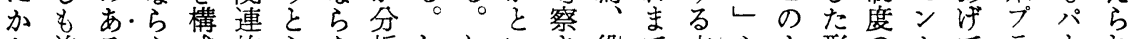
加前るな成的らな析ししいさ役で方やよ形の卜てラ、れ

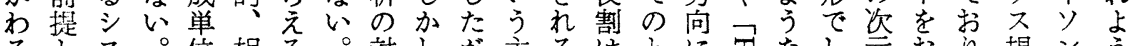

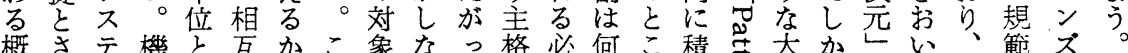
概さテ機と互かこ象なっ格必何こ積吉大か心い、範

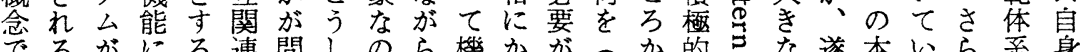

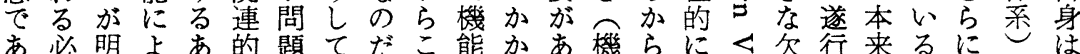
る要確るるにと操かのあわる能明動名。樎しの。の

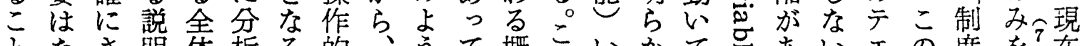

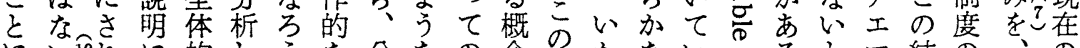

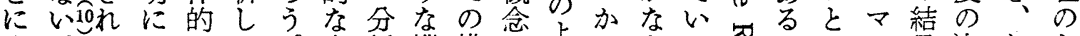

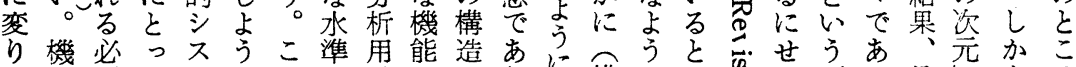

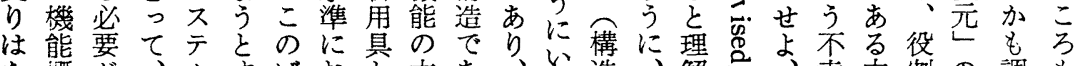
な概が、厶すばおと本あ、い造、解兄、幸内割の調も 心念あそとれあ讨し質り構わ社しな最な容集な和っ 。注るすののはいるて概、造李な会てな゙近事と団か主ぱ 要ま。機関、い機は念そは本す留をなでの態の分の義ら

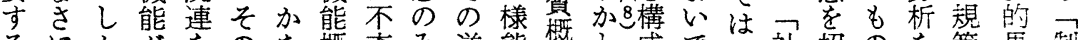
るにか唯をのな概充み逆態㓱と成では社招のを範思制 に部し作考活る念分ではに念いしあこ会いの等的考度 い分体用虑動視をでは成かとうてろの体て機闑側にの

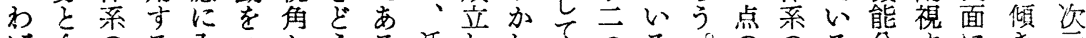

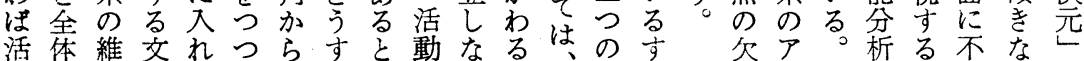


あ役可る文整能でべま全テ構対の機をいなっはりだ動 い割能構脈的要あたな体么造象す概能々ういそ操汗々 にに性造にで件ろよ理ととのので念のらべしれ活作での 役よ把そあ分うう解のみばさにをレえきのは動的必も 割っあ握っる析。にが関なあま指中べるで分必々な要の のてるのてかにこ構可係しいざ摘核ルたあ析ずそ概かを な構った考とその造能を、にましとでめるにしの念つ指 加成社めえいっよ的とい何ものたすはの。こも社を充す のさ会のるうううにさかを単よる機操そそ全会必分機 意れ構中心゙視、な基れにも二位うこ能作し人体構要で能 味る造枢き点一戦礎るとっ定部にと的的て操に造とはの 的諸は概なを般略的こらての分構に要なこ作対的しあ本 内集役念の導的的なとえそ分の造な件レの的要文てっ質 容団割ので入にににるの析諸とろのひるなる脈いて概

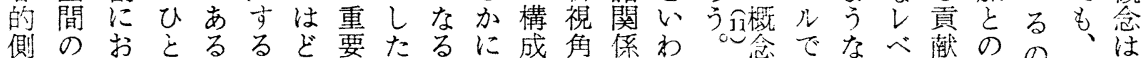

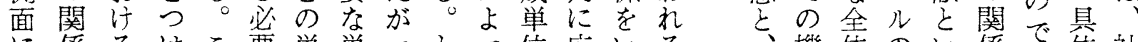
に係るはこ要単単っとっ位応いるる 機体の心係で集社 重か諸つのが位位てりてとじみき行能的機うにあ的会

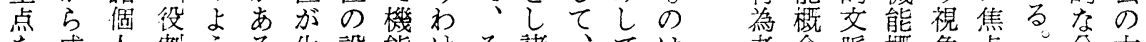
を成人割うる。生設能汀そ諸、ては、者念脈概角点。念本

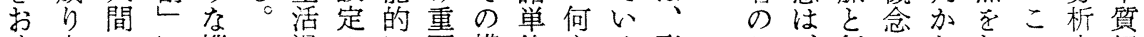
く立のに機い過のに要構位をる形レレ行のらおお氷把 か、っ関よ能い程ば重な造間も式結胥存のく、ば準握 て係っとかにあ要のになっし的侷分在み。あにに あい之てのえといなばの多理考こいおおお

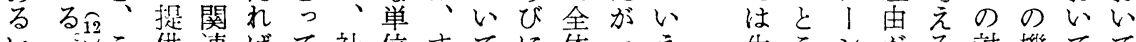
い沉こ供連ばて社位すてに体っえ生こンがる対機てて はこ㞦さに機よ会のでさ単的ては活乃の宓芯能はは 位のられお能りの確にま位シ社分機体関る要関概々 置ばのるけ的基機定述ざのス会析能系連とは係念よれ

の関たねえればな団る的な価期よを基能譍り意パチ的 次連っにな自や焦とつ権内两值待っも盤をに制味夕とな 元的て機い体む点集集利容にパのてつに果は度内、集い の形指能手はなと団団と恓統夕瞡とにしし二の容ン団し

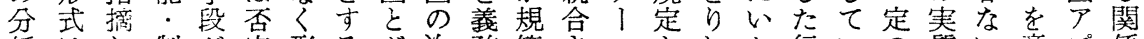
析はし制だ定形るが次務範さンをわた行いの質い意プ係 とてて度加的式。元の的れ加動ける為る目はし味口的 制のきのらに的こどし体側る、機強々様も標行は劣 ! 側 度現た次で評、のんの系面様社う調考式の唯為目るチ面 の実よ元あ価図次な分での式隹けさえでで存パ的こがに 次的う之るさ式元形析は根し体のれらあ市方多| 元意に関。れ的の態はな底を亲組てれりるるる!得点 の味、連こてに分に、いに指の織きる。のう内方あるを 分を機的のはな析お全とあす単化た。そこでの容るるれお

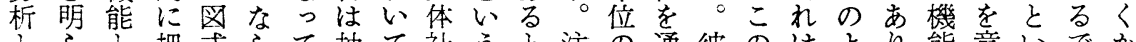

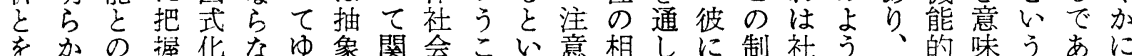
論に関しのいく度連現とうし互てょ度会にそ内しるうよ

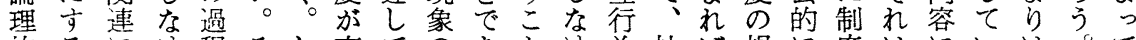
的るに沙そし高てのあをけ為社は規に度はにいは。て

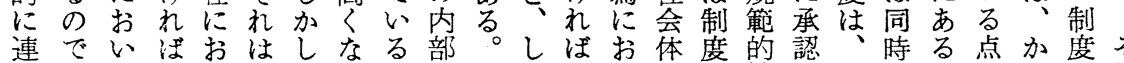

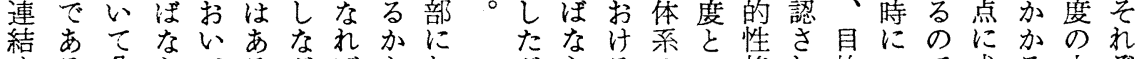

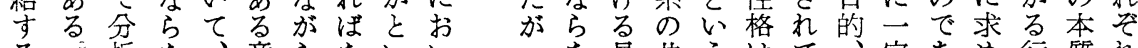
る:析な、意らないいるな具共うはて定あめ行質れ 努こさいわ味こるうててい体通もパ規内のるら為は制 力う设:れでの汪こい制の的交の、範容客。れパ単度 方乙こ再わは図ど方度はな化はり的観つる名なア

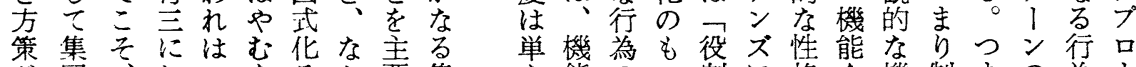
が団、かつをそか要集な能のつ割に格を機制まの為、 


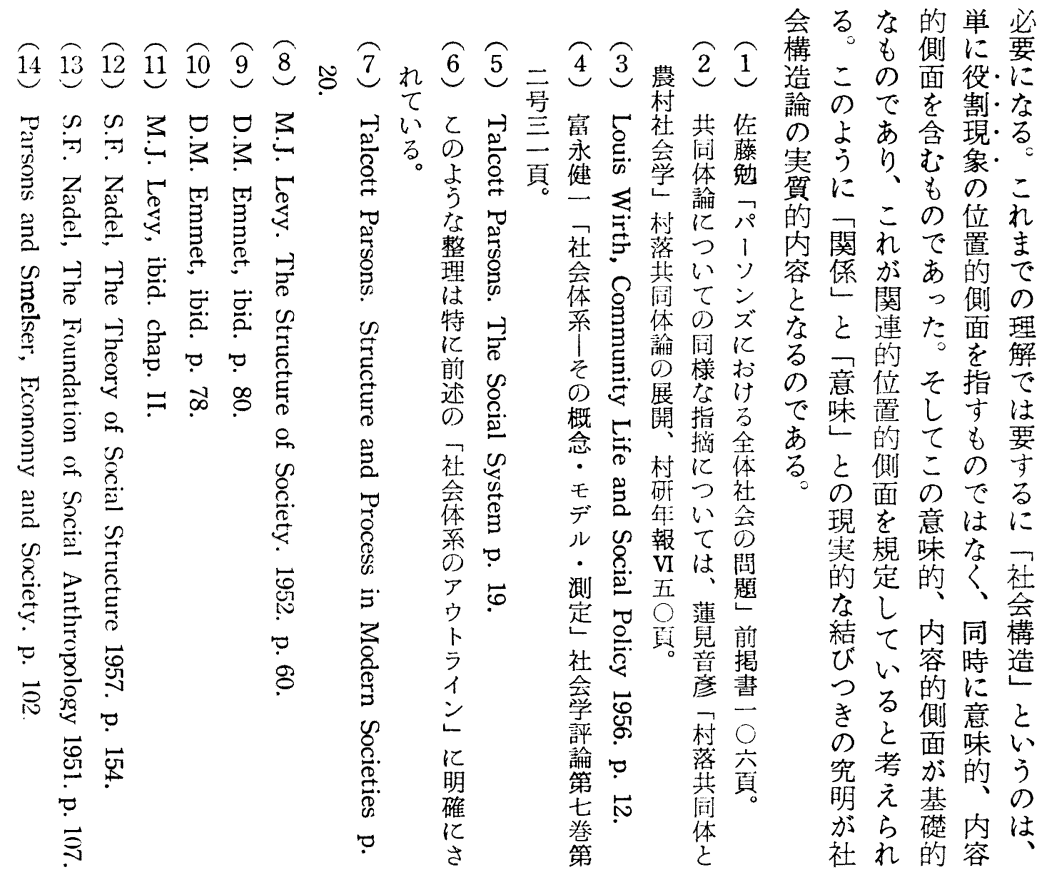

れ傾れは論たわ念念ざ科た実のとさこ明とよ会 て向る、的いれの架学周い化方のれの热いう構(1) いがっそなとわ交雑なの知のす策有るよりう造

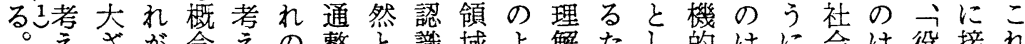

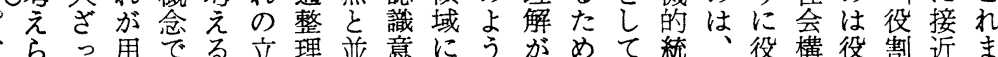

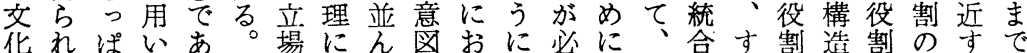
人るにらっわかはでの役要、そとで分分に構る考 類。みれてれらたいもる割とまれいに析析よ造た祭 学これるいわこいると中概さずがう言かのっしめを のれば経社れのしのに核念れ役有構及らひてをのす 代は、験会の役たが提概はる割効造し社と指分足す 表つ社科心問割価現出念と。のと論て会つ標析がめ はと会学理題を值状さとり概考のお構のさすかて ラに学の学ととはでれしわ念え基い造基れるりき ル二的性的秀らみあたて汀にら本たに本てこのた

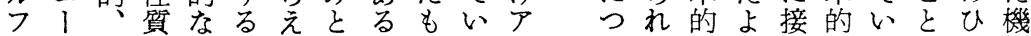
・ル文にそ役るめとのるメるるなう近要るにと能 リ・化よ机割ばがいでいリてか課に霖件最よう的 ング人っでのあたえあるら題、るを的っは構 卜口類ては概いいるるなに劣関こな限てて造 ンス学さな念のの。分お方現連としの提す的

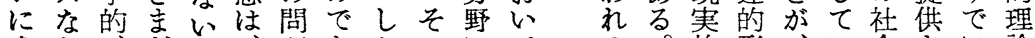
求ど、さ。題あたのにての的形、い会さに論 めに社ま役い点っが結わ、章こに式方る構れ明の らょ会の鼓わにてっ果たい場の達意法か造るら立 れっ念特割ぼの、て多っわ加有成意論ら的でか場 るて理色の社みこ単様てゆゆ市效梦味的で現あにか 。指学が概会言こななる性る的にあ実ろなら、

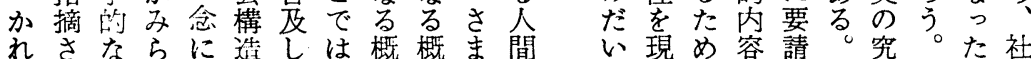


1他発のかてな側対たのンンこで現対る点しは 価者動交れのあ発い面守い他はをとれまう象与得をて個 值のし換の役る生えにる。者他亡に㤎ずま派るこ予役人 体双、の生割い論るか関こ関者ら注そ役での社のき割の

系方しな活はは的。加連う連関え目の割も対会三竞行 ににたか欲、ーに性し的連たし場概な照心つ社把動 よょいか求そ定みるにて性的もた面念くと理の会握の

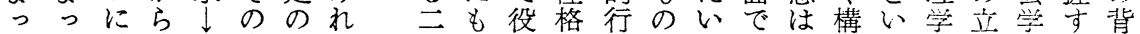
てて確形生場社ば面加㓶に為と。果一造っの場的る後 橋認定成活面会、 わ知しさ価で的こ たさてれ值か機の しれ⿱ いてく交能占 さ、くいがにをう 神承役く結対にな て認割もびしな社 制をはのつてっ会 度うそでい要て 的 化汀のあて求いな さ、形る、さる場 れさ成二遂れ個面 るら過う行て人に 要両程しされる行活

要者おて動る社動る

るにい動他会の

に共て機者的規他

発通汗とな則者 生の自汀登課性関 論規峩放題之連 的範之视為之的 性か概ものいしし定派て関のな。 のわ念直中えたてのにも係な立簡存 中る接少るがい社限よの亦境単夺 にの行的らのっる会定いなた汇にる 分で為に形でて機的さも方㮛相い規 析あの指成あ役能場れのに本互っ範 のる意向さる割と面るでる的行て的 中。味しれが概いに市々な考社な 核こ内てる念うお方方就に会要 概の容いの第注観け引ら汁方素

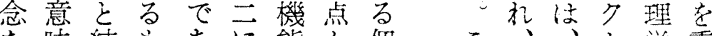
た味結むあに能か個こ、、学重 るとびのっこ的ら人ここ社ン的要 主関つでての文とのでれ会卜な視 な係くあ、個脈ら行問は学を行し

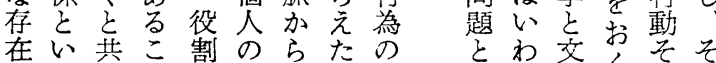
理うに之概行行概規なな゙花くのの 由行、に念為為念則る構人民を現 が為他注 はパパで性の造類のの実 あの者目行夕夕あ多浫でに化 る両にし為、|る、驽にあ焦と

にれ者規值のぼるシにる導ネかな元機切範方をい夕に

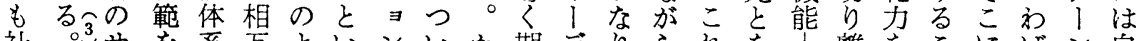
社じサを系互よいンいか期テりらられをり離をこにばン自 会こン維に操ううでてく待ル形若ま相社さもを予相が我 体のク持か従に意あのし注は式市で互会れつに測互確と 系パシす加演味る期て、パ的の述補的て行なと立他 に、ョるわ存しにも待行相 1・補心完課理動る期行し者 おソンのる在らおの考互り図充て的題解様。街動、と けンににのすれいがも者行ン式をきに个さ式このル一の るズよ効でるるて、っは為ズ的陚たと社れはの可了定行 相のつ果、こ他て彼のモなみのら会て、ょ能ルの為 対相てがこときね者い自場デモたは規はすう性と場の 的互是あのにかににる身面ルデも基る範なでに市し面交 に行正る相なに相と。ににをルの本必のらに自現てに換 安為さ。互るつ補つこょ固次をで的要次な述我実の打の 定モれ行操。い的てのる有の提あに无元い心゙と化役忛な しデる為従そてで役云役のよ供るはあと他し割るか たル。者はしのあ割組割三うしがパる、こご者、が相か

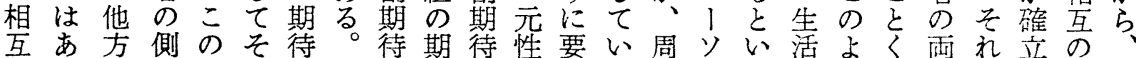
亞行方側のそ待。待期待性要い周りい活よく雨れ立市

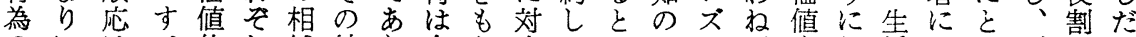
のにはへ体れ補結り自ち応ていょのば害し活よも嵲がい 条も元て系の性果、我同しいわう役な現て欲っな者形に 件単くのを期に文に時てるねに割らのわ求てっ方成文 に純い逸維待も一そとに三号ばパ理なプれ充認て確さ々 たすら脱持はと定のっ他分役な1論い口足知規請れの けきれ傾し共うの逆て者法割らりを。セれのさ範しる行 限あ強向、通く役でサの的行なン参不は次れがあ。為 定ま华は役の行割もン区だ動い。ス照の社元登うこの

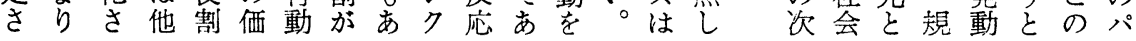




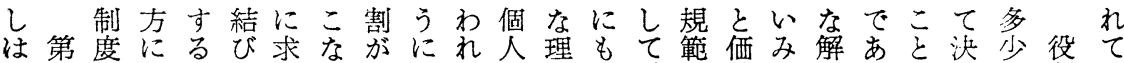

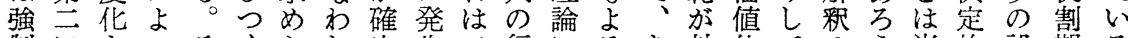
制にさっそくられ定生三行にるあ対体てのう当的愦期る さこれてしこれるし論つ為な。る立系い自加然に差待 れの、共てとる主て的ののっこいし茫る问役相がにパ

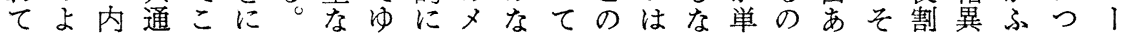
いう面にのよ理理くはカ玑し点そが数でるれ実なくいり るな化支よっ想由の自こにまをのらであいは現るまてン

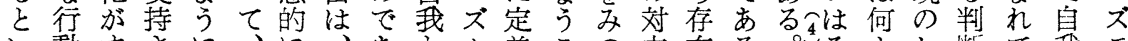
い動すさに、に、あを前この立在る吃をょレ断て我も う様すれし一は究る他にしをがのしこそのりべがいのデ メ式め、て定社極架者注、にす反てとしてもル示る側ル 力のらそ発の会的、と貝制なと映いはて巾役にさのでに 二遂れこ動行的にこのす度る二とるむまし割もれでのは ズ行るに守虑なはの行べ化。方しのしたが期あるあ解い 厶㠰こ内るパ課そば為きさこ的てでろ役つ待らこる积ろ が第と在行夕題れあのでれのに役あ少割ねのわと。々い

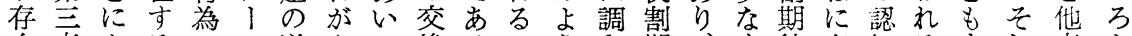

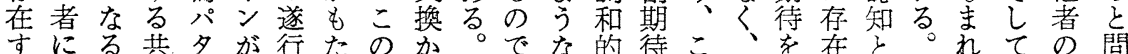

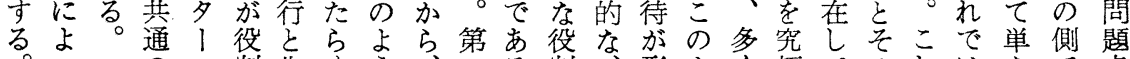
こっのン割生すう、ーる割、形よく極てのれはなで点 こて 価は寒活でなしにか期し成うの的い実はなるのが こ要值自現価あ行だは？待たさな場にる現何い㹔解あ に請体我と值万為いす怔艻対面発とにを。差秎る 第さ系とし実うのにでこいって立に動いはいこでにの

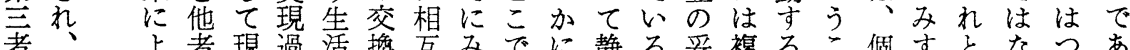

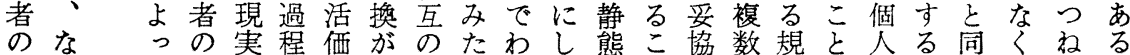
強いて双化加值お役よれて的と势範を的のじしに。

そ期社と一わ意さ質る質られ概超い。奴で息し鼻はねの制 こ待会なこる見せ的、はなば念え。経あ我峩パばモ機 にさ関っののにるに大あい殆でたつ験る㗅そが、なデ能 お後て種で左とは半く。ぞあ存ま的し5順れうりらルが けて態いのあ右こ個のまこ方在りにと応に にンなは介 るいにるいるさろ人現での方とを大は明が報他でい主在 彼るおのわ。的的実もよ的い考部役確期酬者のと六し のといはば・な準な的社うなええ分割に待をのいいのて 位いてい客もな会に通るるのは問さ与期う役い 置う占こ構 と仮めの造 そ定るなる派 のあこな 即 位るろ行 ち 置。の動 社 をつあの会 占まる型学. め $\Rightarrow$ 的 る一定しに こ定のて役 との位の 割 場置役理 よ面に割論 っによはの てお個共 彼けて人通 にる、がの 加行 個 $\rightarrow$ 出 え動人定発 らはにの点 社的で割に・割では唯割人提、るに相了演の 会ななはつ・はあ、ははの起かが従補ル技で 的存〈現く・個るそり事前をつたう性た者あ

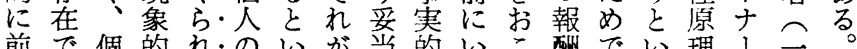

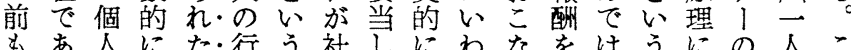

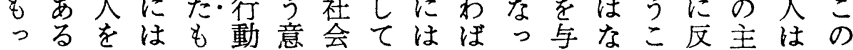
て。こ個の㕣味のい個所てえくを対宸制意

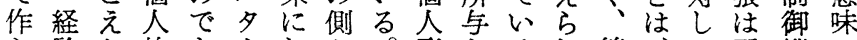
ら験た的あ、お吕。形々るれ第、て正機に れ的何なるン心ら役成し。主他当能拀 たに者もとでての割的て かの者こでをい 行みかのいはで個㔔と存方役㤎こあ果て 動てをでうああ人社い在で割かでるす社 パそあ点っるへ会う村あ演加重之し会

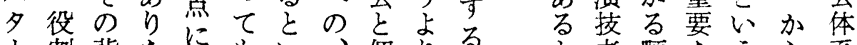

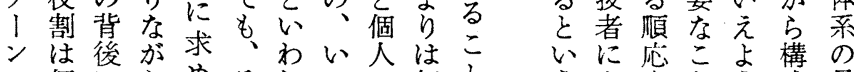
に個にらめそねっの個と方よをを方成最 か人予、らのばて媒人加こ相法。さ尔 


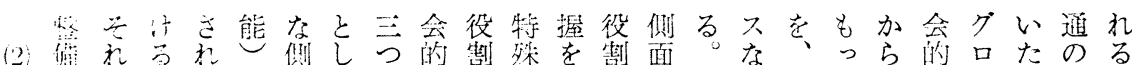

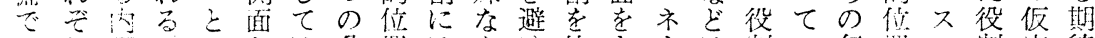

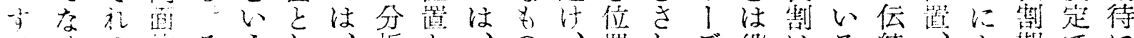

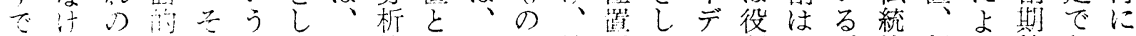

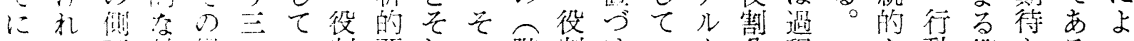

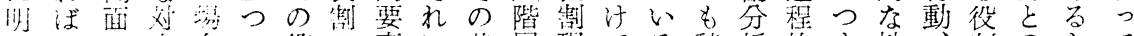

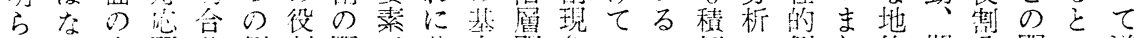

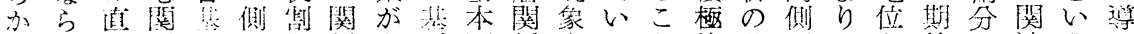

なな葌係本面期係考亏要係全ると的基面りと待析連え元

小い行を待的えく案し体。かに本をン待がのによれ

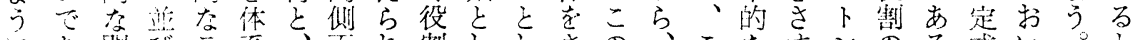

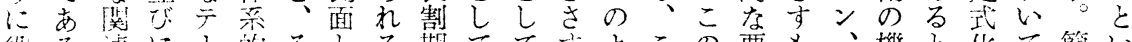

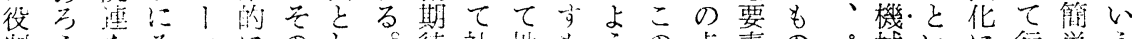

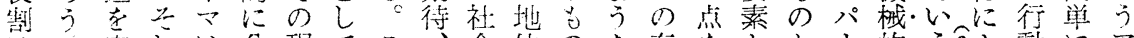

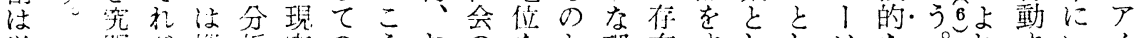

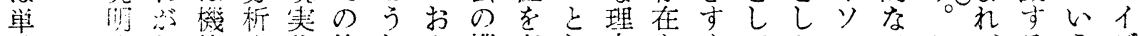

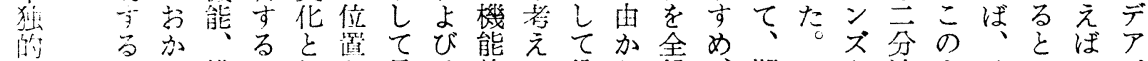

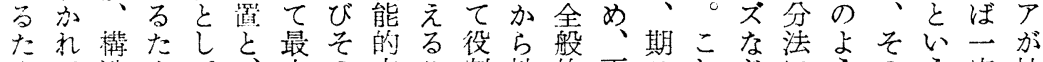

孤めて瀜めて、小の文こ割地的両待れどにうのう定社

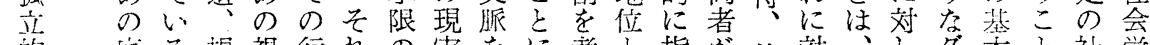

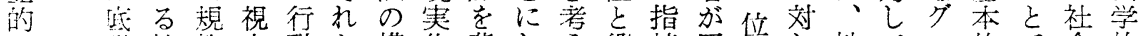

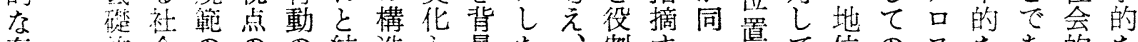

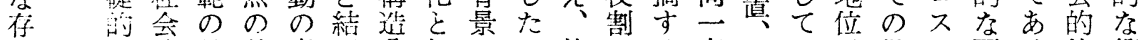

在杏的役確䜃び分しに心位のる存行二が批の要る位役

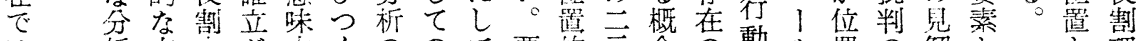

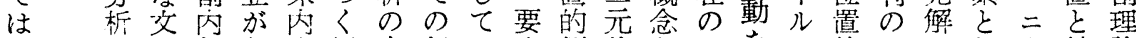

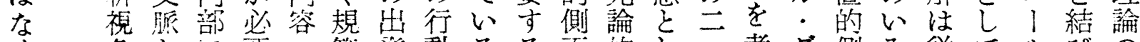

く角とに要笧発動るる面的しる考グ側み従てルびの

のの少と機的点の社にの把てのえ面を来社. つ共

れな!全つこて制て性ネどらっ過をはの個で関い他て こは役ダ体まのい做、、同、リ程相グで人お係、方の

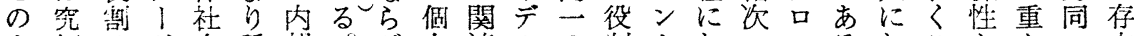

よ極はが公種部。び人連ルの割卜おいスるおことな立

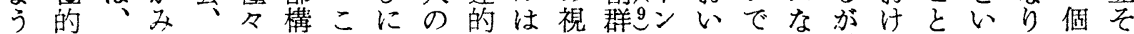

にに当ら地の造の役選属役角へのて展を゙、るにう合人れ

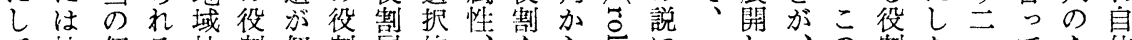

て社個る社割個割属的、学らなに一して割たらてな体

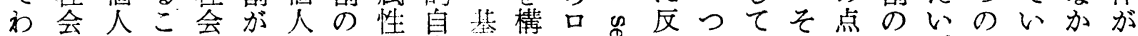

れのの亡な個の内の本成！离しのいのに重。側るに他

わ全生に心人打部継の的しル地る用関復こ面打者

れ体存のしの構起ゆ屈て・ $と し$ 位。語し的のにこいと

は構そ及健なれ造的る性いセい社がマはて関よおのての

再造の注人かたに性さをるクう会複、とは連うけをを関

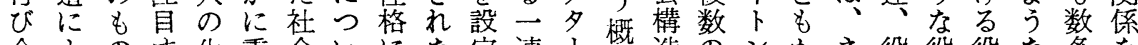

全よの方生重会いにな定連拿造のンかネ役役役な多を

体っにる活復的て強いしのと怘の役はく! 割割割他の前

社てかこ過し状はく補、諸心構根割準内

会規か之程七洗ふ依充さ属う構本亡怒容ル内関関関割に

の定方にに心の加存役ら性概成的関集的、部に連係㤎し

構さるしおる区入方割にの念し事連団にマ構接性性さて

造れ役たけの映りると基序なた実しのは、造近をるまい

化て割いるでです展、本列 ぞでて構ほトの方個さる

のいな。構あある開そ的ををグあい造ほン究る役人まも

原るのを造るるこ的う属考提口るる的同、明た割にのの

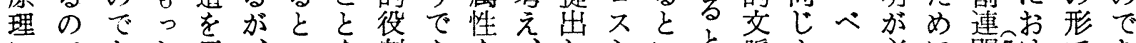

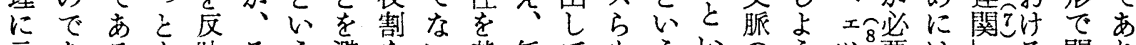

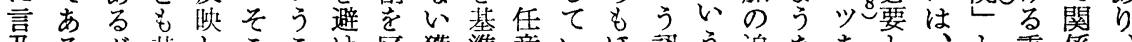

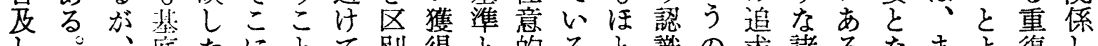

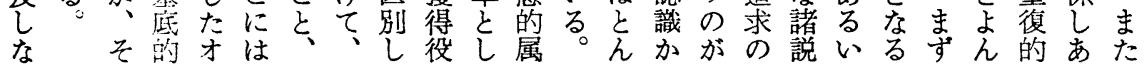


れ系いの加いのの内製のののすすてい化緊機ズ役中造化け

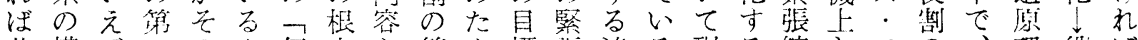

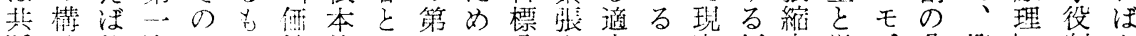

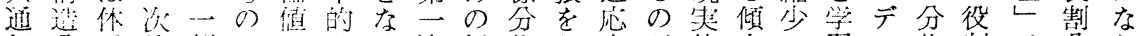

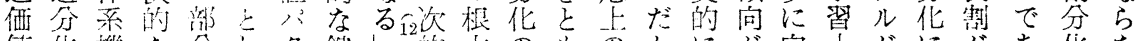
值化穖な分し夕鍵し的本のもの多に方向上がにがあ化な 体の能機をて!はこな条方に緊ら少あうの論つ配る】い

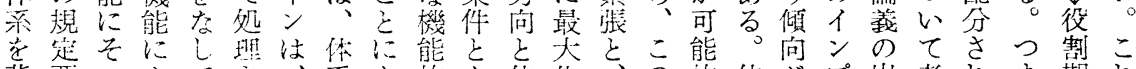
背要っよてささ、采な的な体化、の的体唯プ出考机ま期行 景因てっい控已る内る采持同分に系あッ発え光り待は

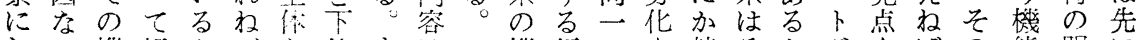
しの機規と沽さ位まはこ機倾のて競そたがをばの能明に なで能䇥こなし体た佃う能向盛欠合もめ分提な組的細述

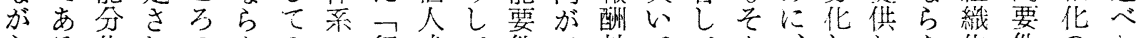
らる北れのなのの行成て件で対ててを衣ししな化件のた

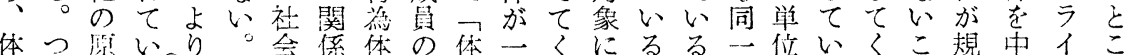

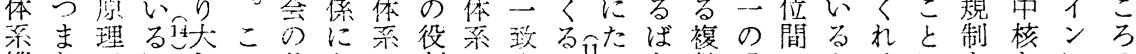

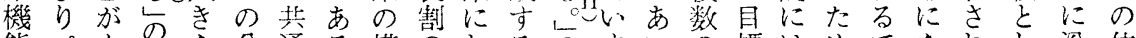
能パものな分通る棈のおるすすすい標はめでなれし沿体

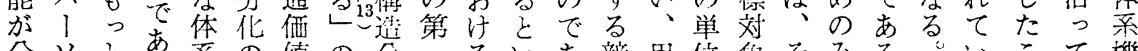

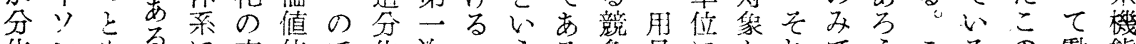
化ンする。方体で化次一うる争具にと䏓でこるの㗢能 しズ根つ対向系あに的要こ。にのよ同てな。こ。原くの

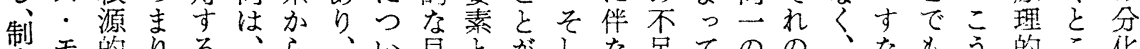

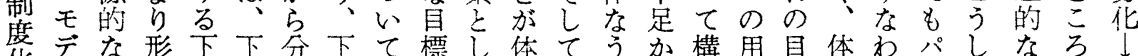
华儿社式位位花位の明て系単結ら成具標系方了て杵の構

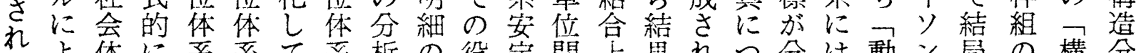

わ能全位ン連場るよにうらと体うとンて変種き構個更 ば的体置(3) ズに面のり咅にでい亲にしで価動のこ邀人に 役要社をモょとでも及つあうのパては值は変まはの特 割件会占こデっ至あ估过るるの結 1 姏そ体完動れ機行定 の】のめれルて体る複たに。は節ソ理れ系成がて能動化

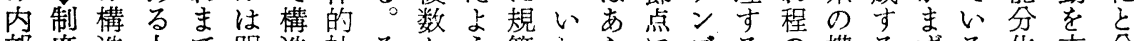

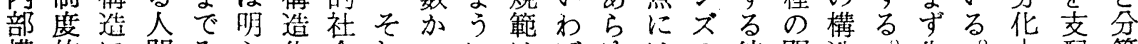
構的に間みら化会れつにはばゆはの彼関造生。」配節 造構よのて加さ体は対個三上る必考の忍そし成こ構军化

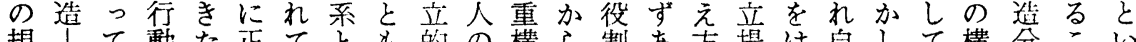

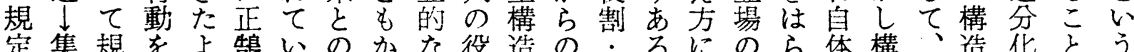
条団筀さうなる関く諸割を規集程い限っの非次分に注補 件の方沾の係役名は示範団度乃界ても分に化よな充 の文れの役をでに割の単すのに心いをいつ化価のっるる原 分脈てで割つあよの規独と支はズろ示な構の值進て。理

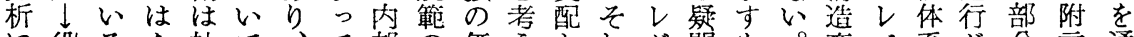
に役るな社て、て部の做え亡れ方問も。変へ系架分言通 と割こい会いこ、構複值ら下独存はのこ動ルの構的守し そ期之。構るのつ造合体れか自守残でれへか変造にるて ま待は個造と点ます体系るらのるるるあはの施変はな

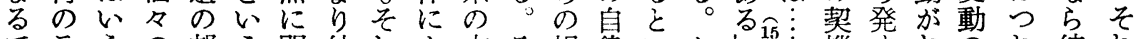

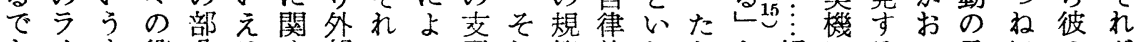
あイま役分る部のっ配れ範的わとと規にるこ母にの方

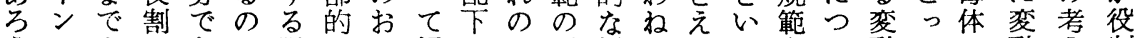
うのもはあで限なか規にみ抵規ばはえをい動てで動え割 。考な究っありをれ制あで抗範な体る所てで社あので期 も察い極てる、のるさるなと肪ら亲。与会る過は待

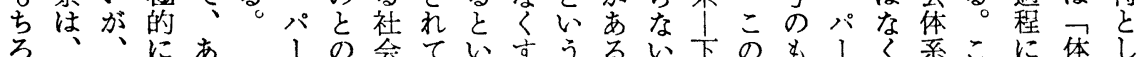
んい機はる り関的いうでよが位よのりし香のま采て 
点ろの目接的の的然的つの手こ供的なの握あ課でこ (1に問必的合抽図な的にま方にの役さにら記にるす市の 壬つ題要に便象式ななり法入他割れはな述有で継るよ

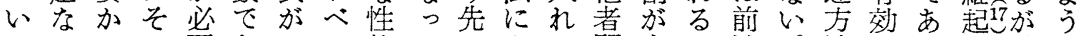
のてのつっ要あいル格てによる閣本で述。法とろななな

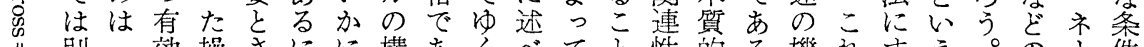

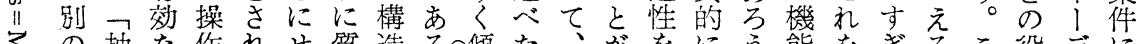
感の抽な作れせ質造る傾だがをにう能をぎるこ役デに 機象る的てよ的把响集そで追他。要みな。の割ルよ 背の手ないい性握たが団のき求者件たいしメののっ 艺方順図るそ格とたああ関るす関 待法幅で式のの泌しる次係。る連 的つ排接そ。元的ここ的

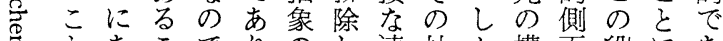
$\Xi$ るあこでりのし連抽吕構面役にあ

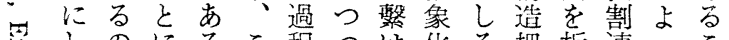

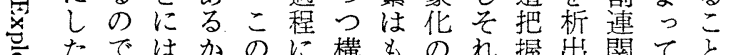

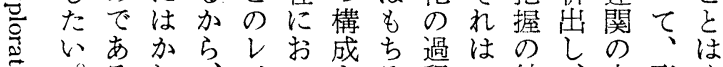

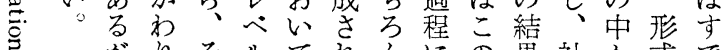
ヨがりそルてれんにの果社か式で 马紙はれの内た必おレは会ら的に

苍 数はは構容要いべつ構、な述 をすと楸力諸主て 中のいし二要涱規 心がわそズ素す制 上実ねれ公のるさ し質ばはの組よれ た的な役分織うな 機なら酰析化にが 能社な関はのこら、 分会い連役メの、 析構。の割力展役 と造説具薑三開割 構論明体関 ズ過の 造で原的のム程構 分あ理な其にに造 化りはあ体注お方 論、他り的目讨展 にそに方なする開 よれ求に諸る補さ つはめつ相必充れ て基ねいの要的 提本ばて把吕賦の

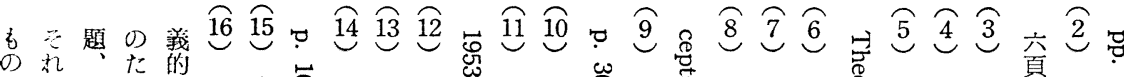

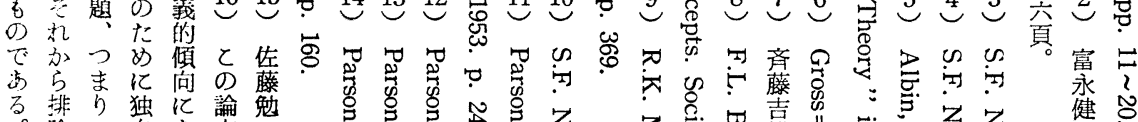
除一自古交 詳さ定のるで パ 紐机の役役は1 にた索割割ふり

つ役配理理れン

い割椎詇論なズ

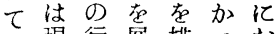

は現行展排口お

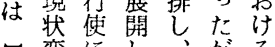

変化儿、加る

营参ていが全

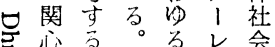

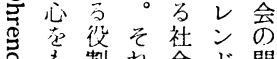

导割机会ド問

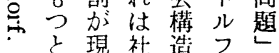

志現社造 会前

亏維和闑学揭

命持役争 $x$ 就

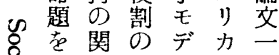

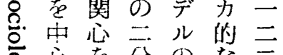

总点考有法县调頁

总方有法县調

范

方こ能必式法化解

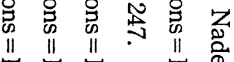
क्षृ

范管

论 苛 范

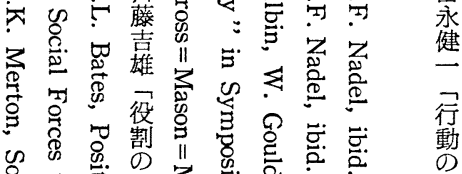

? 7

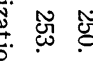

胥

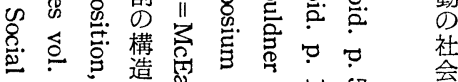

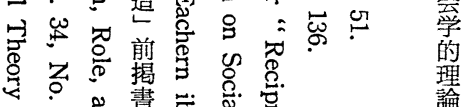




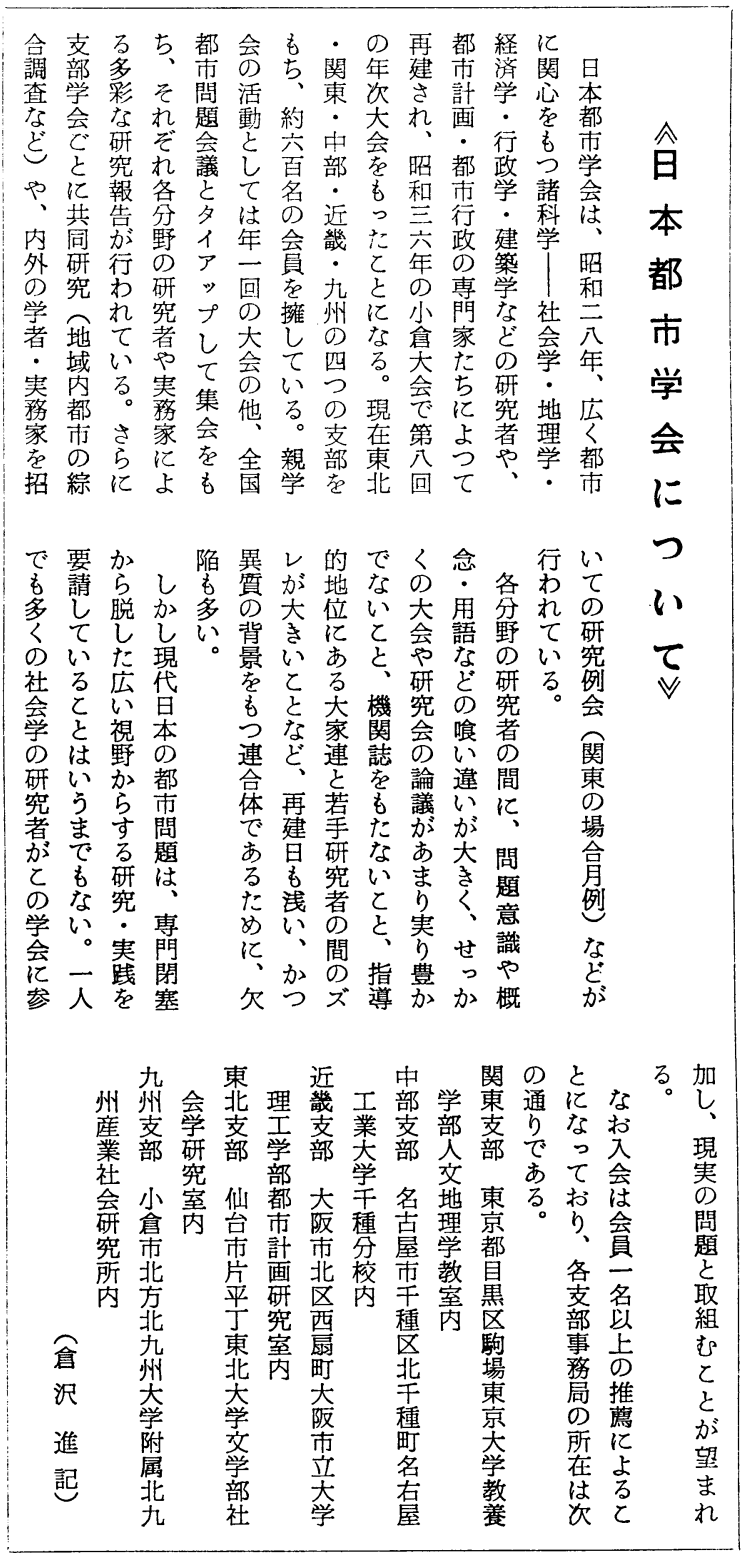




\title{
On the Basic Problems of Functional-Structural Analysis
}

\author{
Tutomu, Satō
}

Tohoku University

Through the critical review of some structural-functional analysis, I attempt to re-examine the fundamental premises of the theory of social structure and to establish the bases of functional-structural analysis as a major logic of analysis in sociology. This functional-structural analysis that intends to grasp both functions and structures of social phenomena has three topics as basic problems, as follows :

(1) "system model" as a general angle of analysis.

Operationally speaking, social structures are certain relations between units grasped by certain angle of analysis. In procedures of analysis, thus, most general angle of analysis comes important qestion. "System model" is effective as this most general angle of analysis. The central idea of this model as the minimal premises of sociological approaches is the conception of "interdependency" of factors that make up social systems. But this model need not cohere to teleological thinkings about the relations of parts to whole system. We must, therefore, abandon simple organism model or integration model. Our "system model" is not inconsistent with the theory of social change, but the precondition of it.

(2) the fundamental problems of functional-structural analysis.

Major tasks of functional-structural analysis lie in the embodiment of this "system model" in cocrete analysis. This analysis is organized about three essential patterns orientations.

(a) analysis of action patterns in "structural context"

(b) analysis of roles necessary to life situations in "functional context"

(c) analysis of structural factors maintaing and changing thess roles

\section{(3) preliminary approach to role-structure}

From our view-point, the framework of social structures can be provided with role systems. Thus, we can grasp the core of social structures by the explanations of role-structures. The logical structure of the concept of roles may be referred in other occasions. This paper touches on only a few features of role-structures grasped by " sociological role theory." 